\title{
Awareness and Practices on Solid Waste Management among College Students in Mindanao State University Maigo School of Arts and Trades
}

\author{
Margarita C. Paghasian \\ Department of Humanities, Education and Social Sciences, Mindanao State University, Philippines \\ margiepaghasian@yahoo.com
}

\begin{abstract}
Every educational institution is mandated by law to educate the public on the theories and practices on solid waste management. To achieve effective and sustainable implementation of the proper waste management practices, awareness with participation is the key to be involved in the Solid Waste Management Program of an institution. Thus, this study was conducted to specifically look into the significant relationship between the awareness and practices on solid waste management among the college students of Mindanao State University - Maigo School of Arts and Trades. A descriptive correlation research design was used in this study with 253 randomly- selected college students. It employed an adopted questionnaire concerning the awareness of solid waste management of the students and their practices. Data were gathered, analyzed and interpreted using the frequency and percentage distribution and chi-square test. Findings showed that the awareness on solid waste management of the students was high; their practices in terms of segregation, reduce and recycle were good; and their practices in terms of recycle and disposal were fair. The awareness on solid waste management of the students had no influence on their practices in terms of disposal however their awareness had affected their practices specifically on segregation, reduce, reuse, and recycle.
\end{abstract}

Keywords: solid waste management, segregation, reduce, reuse, recycle

\section{INTRODUCTION}

Solid waste management is the collection, transport or disposal and treatment of waste materials. It relates to materials produced to human activities, and the process generally undertaken to endure its effects on health, the environment and aesthetics. It reduces or eliminates adverse impacts on the environment and human health rather supports economic development and improved the quality of life. In today's polluted world, learning the correct methods of handling the waste generated has become essential (Marello and Helwege, 2014).

All of the methods of waste prevention and waste management require public participation. Oliva as cited by Villanueva (2013) said that education is an important component of solid waste management that should be present to establish a good program for the community. Awareness of solid waste management will create change on how people look at garbage. People grew up thinking that garbage is garbage, it should not be touched or one should not go near to it. They thought before that all types of garbage should just be thrown in one container (Sarino, 2014). According to Baula as cited by Punongbayan (2014), awareness accompanied by participation is the key for students to be involved in the waste management program of the schools where effective and sustainable implementation of the proper waste management practices could be achieved.

Section 55-56 of Republic Act 9003 or The Ecological Solid Waste Management Act stipulates that the national government in coordination with Department of Education (DepED), Technical Education and Skills Development Authority (TESDA); Commission on Higher Education (CHED) and Philippine Information Agency (PIA), should conduct a continuing education and information campaign on solid waste management and strengthen the integration of environmental concerns in school curricula at all levels, with particular emphasis on the theories and practices of waste management principles like segregation at source, reduction, recycling, re-use and composting, in order to promote environmental awareness and action among the citizenry.

Segregation at source is a solid waste management practice of separating different materials found in solid waste at the point of origin in order to promote recycling and re-use of resources and to reduce the volume of waste for collection and disposal (Article 2, Section 3, RA 9003). Ambayic et al. (2013) cited that reduction is bringing down the amount of trash disposed by consciously buying items that generate a lot of trash. It instills a culture of responsible waste management among students while helping schools reduce their waste. Recycling saves landfill space and also rescues the resources that were used to make another new product. It treats used or waste materials through a process of making them suitable for beneficial use in a way that the original products may lose their identity. In many cases, recycling can also save energy. Schools purchasing paper products made from recycled content help to ensure a viable market for recycled products (Griffiths, et al., 2010).

Reuse is the process of recovering materials intended for the same or different purpose without the alteration of physical and chemical characteristics (Art. 2, Sec. 3, R.A 9003). Re-using saves the energy and resources that would have been used to make a new product and results in less products going into the rubbish bin and ending up in landfill (Griffiths, et al., 2010). When none of the 3Rs options apply, then responsible disposal of the waste is required. One very common irresponsible disposal of waste is littering (Griffiths, et al. 2010). An inquiry was done on the solid waste management program in the Municipality of Maigo, Lanao del Note, Mindanao, Philippines. It yielded results that the people of the municipality had less orientation and awareness about it. Since Mindanao State University - Maigo School of Arts and Trades (MSU-MSAT) is situated in this municipality and as a learning institution, it is covered on the 
mandate of the law initiating actions and positive response towards addressing environmental problems.

The campus has organized the waste management program committee and was commissioned to institutionally implement it. However, as observed, still voluminous wastes are continuously accumulated every week in the campus from various practicum activities specially in shopworks in the different laboratories in the Department of Industrial Technology (DIT) and Department of Hotel and Restaurant Management (DSHRM). The institutional solid waste management committee formulated some policies yet, its full implementation and monitoring were so lax for some reasons. The objective of this study was to find the level of awareness and practices on solid waste management among college students of MSU-MSAT. Specifically, it aimed to achieve the following:

1. To identify the level of awareness on solid waste management of MSU-MSAT college students;

2. To determine their practices on solid waste management in terms of segregation, reduce, reuse, recycle and disposal;

3. To look into the significant relationship between the awareness of the college students and their practices on solid waste management.

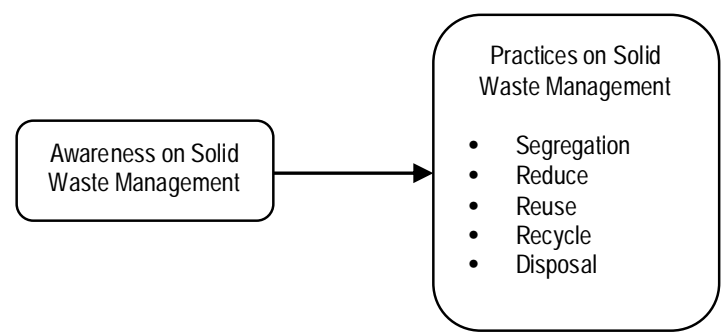

Figure 1 Schematic Presentation of the Study

\section{METHODS}

This study used the descriptive- correlation research design which is used to relate two or more variables. This is used to find significant relationship between the level of awareness and practices of the students on solid waste management. The respondents of this study were the college students of MSU-MSAT. They were chosen because they constituted the greater number of population in the said institution. Out of 1,697 total number of college students, there were 253 randomly selected students during the $2^{\text {nd }}$ semester of the academic year 2015-2016. The sample size was determined by unrestricted random sampling using the formula:

$$
\begin{aligned}
& \mathrm{Ss}=\frac{\mathrm{NV}+\left[\mathrm{Se}^{2}(1-\mathrm{p})\right]}{\mathrm{NSe}+\left[\mathrm{V}^{2} \times \mathrm{P}(1-\mathrm{p})\right]} \\
& \text { Where: } \\
& \mathrm{Ss} \quad=\text { sample size } \\
& \mathrm{N} \quad=\text { total number of population } \\
& \mathrm{V} \quad=\text { standard value of } 2.58 \\
& \mathrm{Se} \quad=\text { sampling error } 0.01 \\
& \mathrm{P} \quad=\text { largest possible proportion } 0.05
\end{aligned}
$$

The main instrument used in gathering data was a questionnaire which had two parts. The first part of the questionnaire was adopted from Abolucion, et al.
(2012) which had 20 statements that were concerned about the level of awareness of the students towards solid waste management. The respondents were asked if they were: fully aware (4), aware (3), not so aware (2) and not aware (1) of the solid waste management. The second part of it was in the form of checklist adopted from Cahoy (2013)t which dealt on the solid waste management practices in terms of segregation, reduce, reuse, recycle and disposal. It had four levels of quality: always (4), often (3), seldom (2) and never (1). The questionnaire was referred to the researcher's adviser for comments, suggestions and corrections. After every correction, the instrument was submitted to the panel and was checked thoroughly by the Thesis Panel for final corrections and modifications.

A letter was drafted to get permission from the office of the campus head for data gathering. After getting the permission, the questionnaire was personally fielded and conducted to the respondents so that the nature and objectives of the study could be explained. The data were gathered, tallied and recorded for statistical treatment, analysis and interpretation. The following tools were used in the analysis of data in this study: Percentage Distribution Formula. This was used to summarize the variables under study.

Formula:

$$
\begin{aligned}
& \mathrm{P}=\frac{\mathrm{f}}{\mathrm{n}} \times 100 \\
& \text { Where: } \\
& \mathrm{P} \quad=\text { percentage } \\
& \mathrm{f} \quad=\text { frequency } \\
& \mathrm{n} \quad=\text { total number of respondents }
\end{aligned}
$$

Weighted Mean. This was used to determine the level of awareness and practices on solid waste management of the students.

Formula:

$$
\begin{aligned}
& \mathrm{X}=\frac{\sum f x}{f} \\
& \text { Where: } \\
& \mathrm{X} \quad=\text { weighted mean } \\
& \mathrm{f} \quad=\text { frequency } \\
& \Sigma \mathrm{fx} \quad=\text { summation of weighted means }
\end{aligned}
$$

Chi-square. This was used to determine the significant relationship between the independent and dependent variable.

Formula:

$$
\begin{aligned}
& \mathrm{X}^{2}=\Sigma \frac{(\mathrm{O}-\mathrm{E})^{2}}{\mathrm{E}} \\
& \text { Where: } \\
& \mathrm{X}^{2} \quad=\text { chi-square } \\
& \mathrm{O} \quad=\text { observed frequency } \\
& \mathrm{E} \quad=\text { expected frequency }
\end{aligned}
$$

To interpret the level of awareness on solid waste management of the students, the scale below was used:

$\begin{array}{ll}3.25-4.00 & \text { Very High } \\ 2.50-3.24 & \text { High } \\ 1.75-2.49 & \text { Low } \\ 1.00-1.74 & \text { Very Low }\end{array}$


To interpret the solid waste management practices, the scale below was used:

$\begin{array}{ll}3.25-4.00 & \text { Very Good } \\ 2.50-3.24 & \text { Good } \\ 1.75-2.49 & \text { Fair } \\ 1.00-1.74 & \text { Poor }\end{array}$

\section{RESULTS AND DISCUSSION}

The results and discussions on the findings relative to the study are arranged in the following order: awareness on solid waste management of the students practices on solid waste management of the students in terms of segregation, reduce, reuse, recycle and disposal significance of the relationship between the awareness of the students and their practices on solid waste management. Awareness on solid waste management, Table 1 shows the level of awareness on solid waste management of the students.

Table 1

Awareness on Solid Waste Management of the Students

\begin{tabular}{|c|c|c|c|c|c|c|c|}
\hline \multirow[b]{2}{*}{ Item } & \multirow[b]{2}{*}{ Descriptions } & \multicolumn{4}{|c|}{ Responses } & \multirow[b]{2}{*}{ GWA } & \multirow[b]{2}{*}{ Interpretation } \\
\hline & & $\begin{array}{c}\text { Fully } \\
\text { Aware }\end{array}$ & Aware & $\begin{array}{l}\text { Not so } \\
\text { Aware }\end{array}$ & $\begin{array}{c}\text { Not } \\
\text { Aware }\end{array}$ & & \\
\hline 1 & Republic Act 9003 & 26 & 87 & 61 & 79 & 2.24 & Low \\
\hline 2 & Solid Waste Management (SWM) Program of the School & 42 & 131 & 42 & 38 & 2.70 & High \\
\hline 3 & School's orientation on SWM Program & 19 & 113 & 74 & 47 & 2.41 & Low \\
\hline 4 & Policies of the SWM program & 16 & 101 & 86 & 50 & 2.33 & Low \\
\hline 5 & Corresponding sanctions of any violations of the SWM program & 21 & 88 & 99 & 45 & 2.34 & Low \\
\hline 6 & Solid waste management committee of the school & 21 & 102 & 90 & 40 & 2.41 & Low \\
\hline 7 & Purpose of the management on implementing the SWM program & 27 & 102 & 86 & 38 & 2.47 & Low \\
\hline 8 & $\begin{array}{l}\text { School's SWM program is a big help in achieving clean and green } \\
\text { environment }\end{array}$ & 55 & 105 & 56 & 37 & 2.70 & High \\
\hline 9 & Importance of the SWM & 49 & 105 & 54 & 45 & 2.62 & High \\
\hline 10 & Practicing SWM saves money and energy & 29 & 111 & 72 & 41 & 2.51 & High \\
\hline 11 & $\begin{array}{l}\text { Student`s roles and responsibilities towards school's SWM } \\
\text { program }\end{array}$ & 29 & 98 & 68 & 58 & 2.39 & Low \\
\hline 12 & Unity is very significant in making up and internalizing the SWM & 43 & 105 & 71 & 34 & 2.62 & High \\
\hline 13 & $\begin{array}{l}\text { Implementation will be successful and effective if concerned } \\
\text { people will participate }\end{array}$ & 45 & 122 & 52 & 34 & 2.70 & High \\
\hline 14 & Discipline on SWM matters a lot & 46 & 121 & 53 & 33 & 2.71 & High \\
\hline 15 & Proper disposal of garbage & 59 & 119 & 32 & 43 & 2.77 & High \\
\hline 16 & $\begin{array}{l}\text { Possible illnesses that you can get whenever trashes are not } \\
\text { properly disposed }\end{array}$ & 49 & 124 & 38 & 42 & 2.71 & High \\
\hline 17 & $\begin{array}{l}\text { Before throwing garbage, it is a must to read those trash-can labels } \\
\text { for segregation }\end{array}$ & 72 & 119 & 26 & 36 & 2.90 & High \\
\hline 18 & Identification of biodegradable from non-biodegradable & 82 & 104 & 32 & 35 & 2.92 & High \\
\hline 19 & Importance of recycling & 79 & 105 & 33 & 36 & 2.90 & High \\
\hline 20 & Waste minimization practices like reuse, recycle and reduce. & 58 & 117 & 34 & 44 & 2.75 & High \\
\hline & Weighted Mean & & & & & 2.60 & High \\
\hline
\end{tabular}

As shown in the table, the highest generalweighted average of 2.92 fell on item 18 , "Identification of biodegradable from nonbiodegradable, interpreted as "High". The least general weighted average of 2.24 fell on item 1, Republic Act 9003, interpreted as "Low". The weighted mean value was 2.60 interpreted as "High". It implies that the students have enough knowledge on solid waste management. They have high level of awareness on the identification of biodegradable from non-biodegradable while low level in Republic Act 9003 or The Ecological Solid Waste Management Act. Table 2 presents the summary of assessment on the level of awareness on solid waste management of the students.

Table 2

Summary on the Level of Awareness of the Students on Solid Waste Management

\begin{tabular}{|c|c|c|c|}
\hline Responses & Interpretation & Frequency & Percentage $(\%)$ \\
\hline Fully Aware & Very high & 65 & 25.69 \\
\hline Aware & High & 133 & 52.57 \\
\hline Not So Aware & Low & 46 & 18.18 \\
\hline Not Aware & Very Low & 9 & 3.56 \\
\hline \multicolumn{2}{|c|}{ Total } & 253 & 100 \\
\hline
\end{tabular}

It showed that out of 253 students, $48.62 \%$ or 123 students were aware on solid waste management, $25.69 \%$ or 65 students had very high awareness, $22.13 \%$ or 56 students had low and only 9 students or $3.56 \%$ had very low awareness on solid waste management. This implies that most of the college students are fully aware on solid waste management. Practices on solid waste management of the students students' practices on solid waste management in terms of segregation.Table 3 shows the students' practices on solid waste management in terms of segregation.

As shown in the table, the highest average weighted value of 2.70 interpreted as "Good" fell under item 1, "I segregate biodegradable (paper, banana peels, cardboard, and vegetables) and nonbiodegradable (plastic toys, glass, steel, rubber) wastes at school". The least weighted value of 2.47 interpreted as "Fair" fell under item 5, "I segregate recyclable items for collection". The weighted mean was 2.61 
interpreted as "Good". This means that the students have good practices on solid waste management in terms of segregation. The students are segregating well biodegradable and non-biodegradable wastes and slightly segregate recyclable items for collection. Table 4 summarizes the practices on solid waste management in terms of segregation.

Table 3

Practices on Solid Waste Management in Terms of Segregation

\begin{tabular}{|c|c|c|c|c|c|c|}
\hline Solid Waste Management Practices & Never & Seldom & Often & Always & GWA & Interpretation \\
\hline \multicolumn{7}{|l|}{ SEGREGATION } \\
\hline $\begin{array}{l}\text { I. I segregate biodegradable (paper, banana peels, cardboard, and } \\
\text { vegetables) and non-biodegradable (plastic toys, glass, steel, } \\
\text { rubber) wastes at school. }\end{array}$ & 29 & 59 & 125 & 40 & 2.70 & Good \\
\hline $\begin{array}{l}\text { 2. I separate recyclable wastes (paper, cardboard, plastic bottles) } \\
\text { from non-recyclable (food wastes, leaves, twigs) wastes at school. }\end{array}$ & 32 & 51 & 134 & 36 & 2.69 & Good \\
\hline $\begin{array}{l}\text { 3. I separate non-harmful wastes from toxic and hazardous wastes } \\
\text { such as pentel pens, laboratory chemicals, ink, cell batteries and } \\
\text { others. }\end{array}$ & 35 & 72 & 110 & 36 & 2.58 & Good \\
\hline 4. I mix all the garbage in one garbage container. & 54 & 75 & 98 & 26 & 2.62 & Good \\
\hline 5. I segregate recyclable items for collection. & 41 & 76 & 111 & 25 & 2.47 & Fair \\
\hline Weighted Mean & & & & & 2.61 & Good \\
\hline
\end{tabular}

Table 4

Summary Table on Students' Practices on Solid Waste Management in terms of Segregation

\begin{tabular}{lccc}
\hline \multicolumn{1}{c}{ Responses } & Interpretation & Frequency & Percentage (\%) \\
\hline Always & Very Good & 53 & 20.95 \\
Often & Good & 129 & 50.99 \\
Seldom & Fair & 60 & 23.72 \\
Never & Poor & 11 & 4.35 \\
\hline & & $\mathbf{2 5 3}$ & $\mathbf{1 0 0}$ \\
\hline
\end{tabular}

It showed that out of 253 students, $50.99 \%$ or 129 of the students had good practices in segregation, $23.72 \%$ or 60 students had fair practices and $20.95 \%$ or 53 students had very good and $4.35 \%$ or 11 students had segregated waste materials poorly. This implies that most of the students have good practices in segregating solid waste. Students' practices on solid waste management in terms of reduce. Table 5 presents the students' practices on solid waste management in terms of reduce.

Table 5

Practices on Solid Waste Management in Terms of Reduce

\begin{tabular}{|c|c|c|c|c|c|c|}
\hline Solid Waste Management Practices & Never & Seldom & Often & Always & GWA & Interpretation \\
\hline \multicolumn{7}{|l|}{ REDUCE } \\
\hline 1. I borrow, share, and/or rent things that are needed occasionally. & 39 & 69 & 121 & 24 & 2.51 & Good \\
\hline $\begin{array}{l}\text { 2. I buy only what I need so that I will not end up throwing away } \\
\text { extra food. }\end{array}$ & 36 & 60 & 102 & 55 & 2.70 & Good \\
\hline $\begin{array}{l}\text { 3. I pack my lunch in reusable lunchbox so that I can't buy } \\
\text { wrapped/packed food at the school. }\end{array}$ & 49 & 56 & 92 & 56 & 2.61 & Good \\
\hline $\begin{array}{l}\text { 4. I bring water in reusable water bottles than buying water in one- } \\
\text { used plastic bottles at the school. }\end{array}$ & 54 & 55 & 114 & 30 & 2.47 & Fair \\
\hline 5. I am cautious and responsible to every waste I produced. & 35 & 52 & 111 & 55 & 2.74 & Good \\
\hline Weighted Mean & & & & & 2.61 & Good \\
\hline
\end{tabular}

The table presents the highest average weighted value of 2.74 interpreted as "Good" fell on item 5, "I am cautious and responsible to every waste I produced". The least average weighted value of 2.47 fell on item 4, "I bring water in reusable water bottles than buying water in one-used plastic bottles at the school", interpreted as "Fair". The weighted mean value was 2.61 interpreted as "Good". This implies that the students have good practices on reducing solid waste. The students are cautious and responsible in every waste they produced and moderately practiced bringing water in reusable water bottles than buying water in one-used plastic bottles at school. Table 6 summarizes the students' practices on solid waste management in terms of reduce.

Table 6

Summary Table on Students' Practices on Solid waste Management in Terms of Reduce

\begin{tabular}{lccc}
\hline \multicolumn{1}{c}{ Responses } & Interpretation & Frequency & Percentage (\%) \\
\hline Always & Very Good & 76 & 30.04 \\
Often & Good & 105 & 41.50 \\
Seldom & Fair & 66 & 26.09 \\
Never & Poor & 6 & 2.37 \\
\hline & & $\mathbf{2 5 3}$ & $\mathbf{1 0 0}$ \\
\hline
\end{tabular}


It showed that out of 253 students, $41.50 \%$ or 105 students of them had good practices on reducing waste; $30.04 \%$ or76 students had very good practices; $26.09 \%$ or 66 of them had fair practices; and $2.37 \%$ or 6 students had practiced poorly. This means that most of the students have commendable practices on reducing solid waste. Practices on Solid Waste Management in Terms of Reuse. Table 7 presents the students' practices on solid waste management in terms of reuse.

Table 7

Practices on Solid Waste Management of the Students in Terms of Reuse

\begin{tabular}{|c|c|c|c|c|c|c|}
\hline Solid Waste Management Practices & Never & Seldom & Often & Always & GWA & Interpretation \\
\hline \multicolumn{7}{|l|}{ REUSE } \\
\hline 1. I reuse my old materials than buying a new one. & 36 & 58 & 118 & 41 & 2.65 & Good \\
\hline 2. I keep those unfilled papers and used it as scratch. & 39 & 53 & 111 & 50 & 2.68 & Good \\
\hline 3. I reuse grocery bags. & 43 & 72 & 97 & 41 & 2.54 & Good \\
\hline 4. I reuse washable food containers. & 41 & 62 & 99 & 51 & 2.63 & Good \\
\hline 5. I reuse scrap paper into memo pads. & 57 & 71 & 103 & 22 & 2.36 & Fair \\
\hline Weighted Mean & & & & & 2.57 & Good \\
\hline
\end{tabular}

The table displayed the highest weighted average value of 2.68 fell on item 2, "I keep those unfilled papers and used it as scratch", interpreted as "Good". The least weighted value of 2.36 fell on item 2 , "I reuse scrap paper into memo pad", interpreted as "Fair". The weighted mean value was 2.57 interpreted as "Good". This signifies that the students have good practices on solid waste management in terms of reuse. The students practiced on keeping unfilled papers and using it as scratch while they fairly practiced reusing scrap paper into memo pads. Table 8 reveals the summary assessment of students' practice on solid waste management in terms of reuse.

Table 8

Summary Table in the Practices on Solid Waste Management of the Students in Terms of Reuse

\begin{tabular}{|c|c|c|c|}
\hline Responses & Interpretation & Frequency & Percentage $(\%)$ \\
\hline Always & Very Good & 78 & 30.83 \\
\hline Often & Good & 120 & 47.43 \\
\hline Seldom & Fair & 47 & 18.58 \\
\hline Never & Poor & 8 & 3.16 \\
\hline \multicolumn{2}{|c|}{ Total } & 253 & 100 \\
\hline
\end{tabular}

It revealed that out of 253 students, $47.43 \% 120$ of them had good practices on solid waste management in terms of reuse, $78 \%$ or 30.83 of them had very good practices, $18.58 \%$ or 47 students had fair practices and $3.16 \%$ or 8 students had practice poorly. This implies that most of the students have acceptable practices on solid waste management in terms of reuse. Practices on solid waste management in terms of recycle. Table 9 reveals the students' practices in terms of recycle.

Table 9

Practice on Solid Waste Management in Terms of Recycle of the Students

\begin{tabular}{|c|c|c|c|c|c|c|}
\hline Solid Waste Management Practices & Never & Seldom & Often & Always & GWA & Interpretation \\
\hline \multicolumn{7}{|l|}{ RECYCLE } \\
\hline 1. I convert or redesign waste materials into a new product. & 47 & 72 & 109 & 25 & \multirow{2}{*}{$\begin{array}{l}2.44 \\
2.39\end{array}$} & Fair \\
\hline $\begin{array}{l}\text { 2. I make decors out of plastic wrappers and other colorful waste } \\
\text { materials. }\end{array}$ & 55 & 72 & 99 & 27 & & Fair \\
\hline 3. I ignore the importance of recycling. & 73 & 51 & 94 & 35 & 2.64 & Good \\
\hline 4. I initiate generating-income out of waste materials. & 52 & 87 & 95 & 19 & 2.32 & Fair \\
\hline Weighted Mean & & & & & 2.47 & Fair \\
\hline
\end{tabular}

It showed the highest average weighted mean of 2.64 interpreted as "Good" fell on item 1, "I ignore the importance of recycling". The lowest average weighted mean of 2.32 fell on item 5, "I initiate generatingincome out of waste materials", interpreted as "Fair". The weighted mean value was 2.47 interpreted as "Fair". This implies that the students have fair practices in recycling waste materials. The students are informed about the importance of recycling but they slightly initiate generating-income out of waste. Table 10 presents the summary on the assessment of students' practices on solid waste management in terms of recycle.

Table 10

Summary Table in the Practices on Solid waste Management in Terms of Recycle of the Students

\begin{tabular}{|c|c|c|c|}
\hline Responses & Interpretation & Frequency & Percentage $(\%)$ \\
\hline Always & Very Good & 63 & 24.90 \\
\hline Often & Good & 83 & 32.81 \\
\hline Seldom & Fair & 94 & 37.15 \\
\hline Never & Poor & 13 & 5.14 \\
\hline \multicolumn{2}{|c|}{ Total } & 253 & 100 \\
\hline
\end{tabular}


It revealed that out of 253 students, $37.15 \%$ or 94 of them, $32.18 \%$ or 83 students, $24.90 \%$ or 63 and $5.14 \%$ or 13 students had fair, good, very good and poor practices in recycling waste materials, respectively. This implies that most of the students do not practice solid waste management in terms of recycling regularly. Practices on solid waste management in terms of disposal Table 11 presents the students' practice on solid waste management in terms of disposal.

Table 11

Practice on Solid Waste Management in Terms of Disposal of the Students

\begin{tabular}{llccccc}
\hline \multicolumn{1}{c}{ Solid Waste Management Practices } & Never & Seldom & Often & Always & GWA & Interpretation \\
\hline DISPOSAL & & & & & & \\
1. I throw and left my garbage anywhere. & 51 & 85 & 42 & 75 & 2.44 & Fair \\
2. I burn waste materials. & 42 & 71 & 84 & 56 & 2.39 & Fair \\
3. I throw waste materials in common open dumps. & 60 & 73 & 96 & 24 & 2.67 & Good \\
$\begin{array}{l}\text { 4. I dispose biodegradable wastes into a compost pit. } \\
\text { 5. I dispose hazardous/toxic/special wastes such as laboratory left- } \\
\text { over (chemicals) or electronic waste in any garbage container. }\end{array}$ & 63 & 69 & 102 & 19 & 2.30 & Fair \\
\hline \multicolumn{1}{|l}{ Weighted Mean } & & 59 & 90 & 66 & 2.27 & Fair \\
\hline
\end{tabular}

As shown in the table, the highest average weighted value of 2.67 fell on item 3 stated, "I throw waste materials in common open dumps", interpreted as "Good". The least weighted average of 2.27 fell item 5, "I dispose hazardous/toxic/special wastes such as laboratory left-over (chemicals) or electronic waste in any garbage container", interpreted as "Fair". The weighted mean was 2.42 interpreted as "Fair". This means that the students have slightly practice proper disposal of garbage. They know that throwing waste materials in common open dumps is not good but they sometimes practice disposing hazardous/toxic/special wastes in any garbage container. Table 12 presents the summary of assessment on the students' practices on solid waste management in terms of disposal.

Table 12

Summary Table in the Practices on Solid waste Management of the Students in Terms of Disposal

\begin{tabular}{lccc}
\hline \multicolumn{1}{c}{ Responses } & Interpretation & Frequency & Percentage (\%) \\
\hline Always & Very Good & 46 & 18.18 \\
Often & Good & 66 & 26.09 \\
Seldom & Fair & 125 & 49.41 \\
Never & Poor & 16 & 6.32 \\
\hline & & $\mathbf{2 5 3}$ & $\mathbf{1 0 0}$ \\
\hline
\end{tabular}

The table revealed that out of 253 students, $49.41 \%$ or 125 of them had fair practices on proper disposal, $29.09 \%$ or 66 students had good practices, $18.18 \%$ or 46 of them had very good practices and $6.32 \%$ or 16 students had practiced proper disposal poorly. This implies that most of the students moderately practice proper disposal. Significance of the Relationship between the Awareness of the Students and Their Practices on Solid Waste Management Table 13 reveals the summary data about the significance of the relationship between the awareness of the students and their practices on solid waste management.

Table 13

Summary Table on the Significance of the Relationship between the Awareness of the Students and their Practices on Solid Waste Management

\begin{tabular}{lccccc}
\hline $\begin{array}{c}\text { Practices on Solid Waste } \\
\text { Management }\end{array}$ & $\mathbf{X}^{\mathbf{2}}$ & df & Probability & CV & Decision \\
\hline Segregation & 11.65 & 4 & 0.05 & 9.488 & Rejected \\
Reduce & 14.88 & 4 & 0.05 & 9.488 & Rejected \\
Reuse & 14.83 & 4 & 0.05 & 9.488 & Rejected \\
Recycle & 12.03 & 4 & 0.05 & 9.488 & Rejected \\
Disposal & 9.14 & 4 & 0.05 & Accepted \\
\hline
\end{tabular}

$\mathrm{H}_{\mathrm{o}}$ : There is no significant relationship between the level of awareness of the students and their practices on solid waste management

The computed chi-square value of 11.65 was greater than the critical value of 9.488 at 0.05 level of probability with 4 degrees of freedom. Hence, the null hypothesis was rejected. This implies that there is a significant relationship between the level of awareness of the students and their practices in terms of segregation. It signifies that if students know very well about solid waste management, practically they can segregate waste according to compostable, recyclable, non-recyclable and special waste.

As seen in the table, the obtained chi-square value of 14.88 was greater than the critical value of
9.488 at 0.05 level of probability with 4 degrees of freedom. Hence, the null hypothesis was rejected. This implies that there is a significant relationship between the level of awareness of the students and their practices in terms of reduce. This means that if the students have good background knowledge on solid waste management, there is a possibility that they can reduce garbage accordingly.

As observed in the table, the obtained chisquare value of 14.83 was greater than the critical value of 9.488 at 0.05 level of probability with 4 degrees of freedom. Hence, the null hypothesis was 
rejected. This implies that there is a significant relationship between the level of awareness of the students and their practices in terms of reuse. This denotes that if students are aware on solid waste management, they can identify and save reusable materials out of wastes.

As manifested in the table, the obtained chisquare value of 12.03 was greater than the critical value of 9.488 at 0.05 level of probability with 4 degrees of freedom. Hence, the null hypothesis was rejected. This implies that there is a significant relationship between the level of awareness of the students and their practices in terms of recycle. This implies that if students are aware on solid waste management, they can recycle things out of waste materials.

The computed chi-square value of 9.14 was less than the critical value of 9.488 at 0.05 level of probability with 4 degrees of freedom. Hence, the null hypothesis was accepted. This implies that there is no significant relationship between the level of awareness of the students and their practices in terms of recycle. This conveys that students know about solid waste management but not able to internalize and practice proper disposal.

\section{CONCLUSION}

This study disclosed the following as its findings: The awareness of the college students was high. Most of them were fully aware in the identification of biodegradable from non-biodegradable and only few of them were knowledgeable on Republic Act 9003. The students had good practices on solid waste management in terms of segregation, reduce and reuse and they had fair practices on recycling and proper disposal. The awareness of the students had no influence to their practices on solid waste management in terms of disposal while the practices of the students in terms of segregation, reduce, reuse and recycle had significant relationship of their awareness on solid waste management.

On the basis of the findings of the study, the following conclusions are drawn: The college students of MSU-MSAT are knowledgeable and mindful on solid waste management. These students have an acceptable habit in segregating, reducing and reusing waste materials while they fall short in recycling and disposing garbage. The awareness on solid waste management of the students does not affect their practices in terms of disposal however their practices in terms of segregation, reduce, reuse and recycle influence their awareness on solid waste management.

The researcher in her desire to find meaning to the effort of this study, submits the following recommendations for possible implications: MSUMSAT should conduct trainings and seminars regularly about Solid Waste Management and allow the students as participants to provide them enough information about it. The Coordinator of Solid Waste Management Program should lead campaigns and give more information about proper practices in segregation, reducing and reusing waste materials in order for the students to have a very good habit on these practices.
The Solid Waste Committee should be consistent in monitoring the students' behavior towards the program.

The Supreme Student Council should purchase more trash bins and put them on conspicuous areas like in the side of the pathways or in every covered shade where the students could easily dispose their garbage properly. The Supreme Student Council should assist the Committee in the monitoring of the program. Teachers should put more emphasis in disseminating information about the importance of the Solid Waste Management program. Students should maintain appreciable practices on Solid Waste Management by attending seminars and orientations. Students should internalize the program and impart their knowledge to others by making themselves responsible of doing it regularly.

The school administration should have information drive/campaign on Solid Waste Management every General Orientation Programs, Convocation Programs and in Homeroom classes to ensure full awareness on the wise disposal of garbage. The Supreme Student Council (SSC) or school student body should have annual plan of action for sustaining Solid Waste Management.

\section{REFERENCES}

[1] Abolucion, D. M. T. 2012. Awareness on Solid Waste Management among the Residents of Dalipuga, Iligan City. Undrgraduate Thesis. Mindanao State University - Iligan Istitute of Technology.

[2] Ambayic, A. S. 2014. Household Practices on Solid Waste Management. Undergraduate Thesis. Mindanao State University - Maigo School of Arts and Trades.

[3] Aquino, A. P. 2013. Ecological Solid Waste Management Act: Environmental Protection through Proper Solid Waste Practices. Retrieved on January 16, 2016, from http://ap.fftc.agnet.org/ ap_db.php?id=153\&print $=1$.

[4] Cahoy, A. Z. 2013. Level of Awareness and Practices on Solid Waste Management among Students in Iligan National High School, Iligan City. Undergraduate Thesis. Mindanao State University -IliganInstitute of Technology. March, 2013.

[5] Christense, T. H. 2011. Solid Waste Technology and Management. United Kingdom: John Wiley \& Sons, Ltd.

[6] Elloso, R. O. 2013. The Perennial Problem of Garbage. Article, Manila Bulletin. Retrieved on April 6, 2016, from http://www.mb.com.ph/the-perennialproblem-of-garbage/.

[7] Griffiths, M. 2010. How to Reduce, Reuse and Recycle Waste in Schools. Retrieved on April 6, 2016, from http://www.ijesd.org/papers/268-CD0082.pdf.

[8] Magante, G. L. M. 2013. The Disaster of NonCompliance to Solid Waste Management Act in the Philippines. Retrieved on January 16, 2016, from http://www.ndcp.edu.ph/publications/12\% 20MAGANTE\%20Solid\%20Waste\%20Management.p df.

[9] Marello, M., and Helwege, A. 2014. Solid Waste Management and Social Inclusion of Waste Pickers: Opportunities and Challenges. Retrieved on April 6, 2016, from http://www.bu.edu/pardee/ files/2014/09/Social-Inclusion-Working-Paper.pdf. 
[10] Mensah-Osei, P. 2014. Characterization of Solid Waste in the Atwima-Nwabiagya District of the Ashanti Region, Kumasi-Ghana. Retrieved on February 12, 2016, from http://www.ijwmt.com/IJWMT_Vol.\%202,\% 20No.\%201,\%20January\%202014/CHARACTERIZA TION.pdf.

[11] National Solid Waste Management Status Report 20082014. 2015. Environmental Management Bureau, Department of Environment and Natural Resources and National Solid Waste Management Commission. Retrieved on April 6, 2016, from http://119.92.161.2/portal/Portals/38/Solid\%20Wastefi naldraft $\% 2012.29 .15$.pdf.

[12] Pollisco, W. C. 2012. Assessment of Policy Gaps, Harmonization of Policies and Needs Analysis in the Management of Solid Waste in the Philippines Final Report. Retrieved on January 16, 2016, from http://enrdph.org/wp-content/uploads/2014/05/FinalReport.pdf.

[13] Premakumara, D. G. J. 2013. Policy Implementation of the Republic (RA) 9003 in the Philippines: A Case Study of Cebu City. Retrieved on April 6, 2016, from file:///C:/Users/Administrator/Downloads/6-5.pdf.

[14] Punongbayan, C. M. 2014. Waste Management Practices of an Educational Institution. Retrieved on January 16, 2016, from http://apjeas.apjmr.com/wpcontent/uploads/2014/09/APJEAS-2014-1-056.pdf.

[15] Recycling and Waste Reduction. 2015. A Guide for Schools - Wisconsin Department of Natural Resources. Retrieved on April 6, 2016, from http://www.seas.columbia.edu/earth/wtert/sofos/Dolly_ Shin_Thesis.pdf.

[16] Republic Act No. 9003. The Ecological Solid Waste Management Act of 2000. Retrieved on January 16, 2016, from http://www.gov.ph/2001/01/26/republicact-no-9003-s-2001/.

[17] Sarino, M. A. O. 2012. Proper Waste Disposal Makes for Disaster-free Communities. Article, Manila Bulletin. Retrieved on April 6, 2016, from http://www.mb.com.ph/proper-waste-disposal-makesfor-disaster-free-communities/.

[18] Solid Waste Management in Schools. 2016. Ecosan Services Foundation. Retrieved on January 16, 2016, from http://schoolsanitation.com/pdf/WasteManagement-in-Schools.pdf.

[19] Villanueva, R. 2013. Proper Solid Waste Management: Education, Engineering, Enterprise and Enforcement. Article.The Philippine Star. Retrieved on April 6, 2016, from http://www.philstar.com/science-andtechnology/2013/01/03/892576/proper-solid-wastemanagement-education-engineering. 